\title{
Renal Benefits of SGLT 2 Inhibitors and GLP-1 Receptor Agonists: Evidence Supporting a Paradigm Shift in the Medical Management of Type 2 Diabetes
}

\author{
Vjera Ninčević ${ }^{1,2}$, Tea Omanović Kolarić ${ }^{1,2}$, Hrvoje Roguljić ${ }^{1,3}$, Tomislav Kizivat ${ }^{4,5}$, \\ Martina Smolić ${ }^{1,2}$ and Ines Bilić Ćurčić ${ }^{1,6, * \mathbb{D}}$ \\ 1 Department of Pharmacology, Faculty of Medicine, Josip Juraj Strossmayer University of Osijek, J. Huttlera 4, \\ 31000 Osijek, Croatia; vnincevic@mefos.hr (V.N.); tomanovic@mefos.hr (T.O.K.); \\ hrvoje.roguljic@mefos.hr (H.R.); martina.smolic@mefos.hr (M.S.) \\ 2 Department of Pharmacology and Biochemistry, Faculty of Dental Medicine and Health, Josip Juraj \\ Strossmayer University of Osijek, Crkvena 21, 31000 Osijek, Croatia \\ 3 Department for Cardiovascular Disease, University Hospital Osijek, 4, 31000 Osijek, Croatia \\ 4 Clinical Institute of Nuclear Medicine and Radiation Protection, University Hospital Osijek, 31000 Osijek, \\ Croatia; tkizivat@mefos.hr \\ 5 Department for Nuclear Medicine and Oncology, Faculty of Medicine, Josip Juraj Strossmayer University of \\ Osijek; J. Huttlera 4, 31000 Osijek, Croatia \\ 6 Department of Diabetes, Endocrinology and Metabolism Disorders, University Hospital Osijek, \\ 31000 Osijek, Croatia \\ * Correspondence: ibcurcic@mefos.hr
}

Received: 30 October 2019; Accepted: 18 November 2019; Published: 20 November 2019

check for updates

\begin{abstract}
Diabetic nephropathy (DN) is one of the most perilous side effects of diabetes mellitus type 1 and type 2 (T1DM and T2DM).). It is known that sodium/glucose cotransporter 2 inhibitors (SGLT 2i) and glucagone like peptide-1 receptor agonists (GLP-1 RAs) have renoprotective effects, but the molecular mechanisms are still unknown. In clinical trials GLP-1 analogs exerted important impact on renal composite outcomes, primarily on macroalbuminuria, possibly through suppression of inflammation-related pathways, however enhancement of natriuresis and diuresis is also one of possible mechanisms of nephroprotection. Dapagliflozin, canagliflozin, and empagliflozin are SGLT2i drugs, useful in reducing hyperglycemia and in their potential renoprotective mechanisms, which include blood pressure control, body weight loss, intraglomerular pressure reduction, and a decrease in urinary proximal tubular injury biomarkers. In this review we have discussed the potential synergistic and/or additive effects of GLP 1 RA and SGLT2 inhibitors on the primary onset and progression of kidney disease, and the potential implications on current guidelines of diabetes type 2 management.
\end{abstract}

Keywords: diabetic nephropathy; diabetes mellitus; GLP-1 receptor agonists; SGLT2 inhibitors; molecular mechanisms

\section{Introduction}

Diabetic nephropathy (DN) is a complication of diabetes mellitus, both type I and II, caused by changes in microvasculature [1], and which can lead to end-stage renal disease and cardiovascular disease [2,3]. Moreover, it is the leading cause of chronic kidney disease, affecting 30-40\% of patients with diabetes mellitus type 1 and $25-40 \%$ of patients with diabetes type 2 [4-7].

In its classic definition DN is defined as increased protein excretion in urine [8]. Major representations of diabetes in renal disease include persistent albuminuria, loss of podocytes, glomerular 
hypertrophy, matrix expansion, and thickening of the glomerular basement membrane $[9,10]$. The first stages of DN are characterized by microalbuminuria, a small increase in albumin excretion in urine [11-13]. Later stages are defined by macroalbuminuria or proteinuria leading to a decreased glomerular filtration rate [8].

Pathogenesis and progression of diabetic kidney disease are most likely a result of interactions between metabolic and hemodynamic changes which are caused by onset of diabetes [14], but also other factors including genetic predisposition [15], generation of reactive oxygen species (ROS) caused by hyperglycemia [14-16], and inflammation [17].

Studies have shown that diabetic kidney disease can lead to end stage renal disease in $30-40 \%$ of diabetes mellitus (DM) patients [18], implying that genetic variations could have impact on the start and progression of DM and the end stage renal disease. Genome-wide studies have been conducted to identify potential candidate genes of importance to DM and diabetic kidney disease [19]. More than fourteen genes have been identified as important to the development of diabetic kidney disease, among which are genes controlling lipid metabolism (ADIPOQ), glucose metabolism (GCKR), angiogenesis (EPO promotor gene), genes related to renal structure and function (SHROOM3), inflammation and oxidative stress related genes (TGF- $\beta 1$ ), renin-angiotensin-aldosterone system related genes (AGTR1), and others [15]. Still, the complete effects of these genes and their variants are not completely clear. Results from these studies cannot be replicated among different races indicating race-specific gene polymorphisms or still significant environmental impacts.

Inflammation and chronic high levels of circulating glucose and its end metabolites are main causes of tissue damage in DM by, among other, creating high levels of oxidative and nitrosative stress in kidneys [20,21]. The effects of oxidative stress in other renal diseases like urolithiasis have been described [22]. High production of ROS and nitrosative species (NS) can cause damage to nuclear and mitochondrial DNA, induce apoptosis, and cause endoplasmic reticulum stress, and with this playing a role in cell death pathways such as apoptosis and necrosis in key cell types such as podocytes [20].

Considering the structural changes in diabetic kidney disease, they are similar in both DM1 and DM2, but are more heterogeneous and less predictable in association with clinical presentation in DM2 [23], probably because DM2 has unreliable onset timing, longer exposure to hyperglycemia before diagnosis, older patients, and patients that are treated with renin-angiotensin inhibitors before the onset of diabetes [24].

These structural alterations encompass modifications of several kidney departments. One of the first changes is thickening of the glomerular basal membrane, becoming apparent at 1.5 to 2 years from the diagnosis of DM, and which is closely followed by thickening of the capillary and tubular basement membrane [25-28]. Glomerular changes later include mesangial matrix expansion, loss of endothelial fenestrations, and loss of podocytes with effacement of foot processes [25]. The first signs of mesangial volume expansion are seen after 5-7 years of DM1 onset [27-30]. As DM progresses, segmental mesangiolysis appears and is considered to be connected with the development of micoaneurysms and Kimmelstal-Wilson nodules [31,32]. Subendothelial deposits of proteins forming periodic acid-Schiff-positive and electron-dense deposits accumulate in small arterioles, glomerular capillaries and microaneurysms result in exudative lesions and can cause luminal compromise [25]. Subepithelial deposits similar to subendothelial can be seen in Bowman's capsule and renal tubules. In the later stages of DM, glomerulopathy and interstitial changes grow together to segmental and global sclerosis [25]. Glomerular filtration, albuminuria, and hypertension in DM1 are strongly correlated with mesangial expansion, but to a less degree with glomerular basement membrane width [25]. 


\section{GLP-1 Agonists in Diabetic Nephropathy}

\subsection{Classes of GLP-1 RA and Mechanism of Action}

Glucagon-like peptide-1 (GLP-1) receptor agonists (RAs), an antidiabetic class of drugs, are known for their proven efficacy and safety profile [33]. They can be divided into human originated GLP-1 RAs, synthesized by various modifications of human GLP-1 active fragments, and agents derived from reptile Gila monster venom (exendin-4) [33,34]. Another classification of GLP-1 RAs is based on their pharmacokinetic profile, which divides these drugs into two different groups: short-acting (exenatide twice daily and lixisenatide) and long-acting agonists (once-weekly injected; dulaglutide, liraglutide, semaglutide, albiglutide) [33,34]. The half-lives of GLP-RAs vary between 2-3 h for short-acting agonists and $13 \mathrm{~h}$ to 7 days for long-acting agonists [33]. Up-to-date, above-mentioned 6 GLP-1 RAs have been approved for the treatment of patients with type 2 diabetes mellitus (T2DM), and all these drugs are administered by subcutaneous injection [33]. In general, GLP-1 RAs exert various beneficial effects in T2DM: enhancement of glucose-dependent insulin secretion, acceleration of $\beta$-cells proliferation and inhibition of $\beta$-cells apoptosis, inhibition of motility and gastric emptying, and a stimulation of the sensations of satiety and fullness by direct action on the central nervous system, with reduction in body weight [34-37]. Many other effects are still being investigated, among them reduction in systolic and diastolic blood pressure and improvements in lipid profile [33,38-42]. The main difference between the two groups is the fact that short-acting GLP-1 RAs while delaying gastric emptying, mostly lower postprandial plasma glucose, whereas the long-acting agonists predominantly exhibit insulinotropic and glucagonostatic actions, consequently exerting a much greater effect on fasting glucose concentrations. Various meta-analysis showed that long-acting agonists were more successful in lowering $\mathrm{HbA}_{1 \mathrm{C}}$ compering to short-acting agonists [33,41,43-47]. More specifically, these studies demonstrated that the largest reduction in $\mathrm{HbA}_{1 \mathrm{c}}$ values was associated with dulaglutide and exenatide once weekly, whereas the smallest mean reduction was observed with albiglutide [48]. The same results were observed when comparing the effects on the reduction of body weight [33]. The advantages of liraglutide in comparison with exenatide were: less frequent nausea and vomiting (shorter duration of GI side effects at the beginning of the therapy), more efficacy in lowering glycemic parameters, fasting glucose, and improving the homeostatic model assessment of $\beta$ cells [34]. Generally, the most often side effects of GLP-1 RA therapy are gastrointestinal events (nausea, vomiting, diarrhea; shorter duration in short-acting agonists because of their lack of substantial effects on gastric emptying), and injection-site reactions (notable for albiglutide and lixisenatide), immunogenicity (exendin-4 derivates are more likely to be associated with the development of antidrug antibodies compared to GLP-1 RAs modified from human GLP-1) [33,49,50]. Nevertheless, these adverse events are rarely serious or persistent, nor the cause of discontinuation of therapy, especially because of the high efficiency of these drugs.

\subsection{Potential Nephroprotective Actions of GLP-1 Agonists}

Among all the above-mentioned therapeutic effects (lowering glucose, reducing body-weight etc.), GLP-1 RAs exert possible nephroprotective effects in T2DM, which have been demonstrated in various studies. Yin W et al. showed that GLP-1 RAs reduced albuminuria and ameliorated kidney tubules and tubulointerstitial lesions in the diabetic nephropathy rats model [51]. GLP-1 RAs downregulated the expression of tubulointerstitial tumor necrosis factor alpha (TNF $\alpha)$, monocyte chemoattractant protein-1(MCP-1), collagen I, alpha-smooth muscle actin ( $\alpha$-SMA), and fibronectin (FN) which are all reported to play a role in the diabetic nephropathy [51]. Additionally, the level of C-peptide, which was found to inhibit tubulointerstitial fibrosis [52], was increased by GLP-1 RAs and this may be one of the ways of improving tubuluinterstitial and tubular injury in GK rats with diabetic nephropathy [51]. In the study of Kodera et al. various beneficial effects of exendin-4 were showed, with emphasis on the prevention of macrophage infiltration, decrease of protein levels of intercellular adhesion molecul-1 (ICAM-1) and type IV collagen in glomeruli, as well as the decrease of oxidative stress 
(downregulation of Nox4 gene expression) and nuclear factor-kB (known for contributing to cross-talk between inflammation and oxidative stress) activation in kidney tissue [53]. Furthermore, liraglutide is capable of inhibiting $\mathrm{NAD}(\mathrm{P}) \mathrm{H}$ oxidase through generation of cAMP, followed by activation of PKA or Epac2 [54-57]. Hendarto et al. confirmed the role of liraglutide in the normalization of oxidative stress markers and expression of renal NAD(P)H oxidase components (Nox4, gp91phox, p22phox, p47phox) in diabetic rats, but independently of lowering plasma glucose levels [58]. Similar results were demonstrated in the mouse model of diabetic nephrophathy with the crucial role of liraglutide in protection against renal oxidative stress and lowering of fibronectin accumulation in glomerular capillary walls [59]. Molecular mechanisms included in these actions are inhibition of NAD(P)H oxidase and activation of cAMP-PKA pathway as already explained [59]. The in vitro beneficial effects of liraglutide were also showed in various studies. Zhao et al. proved that liraglutide enhances cell viability in HK-2 cells (human proximal tubular cells) by downregulating caspase-3 expression [37]. Furthermore, mRNA and protein expression of GLP-1R was significantly enhanced by liraglutide, whereas the expression of the autophagic markers LC3-II and Beclin1 was ameliorated [37]. All these effects were blocked by the GLP-1R antagonist exendin-(9-39) [37]. Additionally, another study on HK2 cells treated with GLP1 RAs showed decrease in the expression of profibrotic factors like fibronectin, $\alpha$-SMA, collagen I, and TNF $\alpha$ [51]. In the same study GLP-1RAs inhibited the activity of NF- $k B$ and p38MAPK (two significant signaling pathways for kidney fibrosis) via GLP-1R [51]. Various studies confirmed the role of GLP-1RAs in water and electrolyte balance. One of the suggested mechanisms for this effect is inhibition of intestinal sodium-hydrogen exchanger isoform 3 (NHE3) activity [60]. This NHE3 exchanger is located on the renal proximal tubule, and GLP-1RA, by inhibiting its activity, enhance natriuresis and diuresis [61]. Accordingly, when adding GLP-1R blocker exendin-9, a decrease in renal excretion of sodium and water is observed [62]. Furthermore, exendin-9 has been connected with slight decrease in glomerular filtration rate (GFR), although it would be expected to increase GFR by increasing proximal tubular reabsorption, followed by inhibition of tubuloglomerular feedback signals and reduction in afferent arteriolar resistance [62]. However, this implicates another possible positive effect of GLP-1RA on nephroprotection and water/sodium balance [62]. Glomerular hyperfiltration enhanced by GLP-1RAs increases filtration and in the end excretion of electrolytes [61]. Finally, all these studies, which show the beneficial effects of GLP-1RAs in diabetic glomerular, tubulointerstitial, and tubular nephropathy, implicate the possible clinical use of these agents in treatment of diabetic nephropathy.

\subsection{Assessment of Nephroprotective Effect of GLP-1 Receptor Agonists in Clinical Trials}

Recent clinical trials demonstrate notable evidence of glucagon-like peptide-1 (GLP-1) agonists exerting renal benefits.

Between June 2012 and August 2013 the LIRA-RENAL trial examined the efficacy and safety profile of liraglutide in diabetic patients with moderate renal impairment (defined as eGFR 30-59 mL/min/1.73 $\mathrm{m}^{2}$ ) [63]. This double blinded, randomized, placebo-controlled trial included 279 patients with type 2 DM who had $\mathrm{HbA} 1 \mathrm{c}$ in the range of $7 \%$ to $10 \%$. Addition of liraglutide to background glucose-lowering therapy reduced $\mathrm{HbA} 1 \mathrm{c}$ more than placebo treatment $(-1.05 \%$ vs. $-0.38 \%)$. During the trial no deterioration of renal function was observed in patients treated with liraglutide in comparison with placebo. Furthermore, albuminuria assessed as the urinary albumin-to-creatinine ratio showed lower increase at week 26 in patients treated with liraglutide, although it was not significantly.

A more extensive and longer study of liraglutide treatment effect on renal outcomes in patients with diabetic nephropathy was the Liraglutide Effect and Action in Diabetes: Evaluation of Cardiovascular Outcome Results (LEADER) trial [64]. The LEADER trial included 9340 patients with type 2 diabetes and a high risk of cardiovascular disease with a median follow-up of 3.84 years. $23.1 \%$ of the trial population had mean estimated GFR less than $59 \mathrm{~mL}$ per minute per $1.73 \mathrm{~m}^{2}$; and furthermore, microalbuminuria and macroalbuminuria were present at the baseline ( $26.3 \%$ and $10.5 \%$, respectively). The renal outcome showed a lower rate of occurrence in the liraglutide group in comparison with 
placebo (5.7\% vs. $7.2 \%)$. That was primarily the result of lower incidence of new-onset persistent macroalbuminuria in patients treated with liraglutide (3.4\% vs. $4.6 \%)$. During the follow-up the urinary albumin-to-creatinine ratio growth was slower in liraglutide group while decline of estimated GFR and the rates of renal adverse effects were similar between the two groups. Interestingly, the effect of liraglutide on composite renal outcomes showed no difference in prespecified subgroups of patients with an elevated baseline renal risk, suggesting effectiveness of the liraglutide renal benefit to be an independent factor of stage of chronic kidney disease.

While the LEADER trial included patients with macroalbuminuria from the baseline to the onset of sustained albuminuria in the endpoint, the Evaluation of Lixisenatide in Acute Coronary Syndrome (ELIXA) trial assessed renal outcomes in patients only with normoalbuminuria or microalbuminuria [65]. This randomized, double blinded study primarily examined the effect on cardiovascular outcomes of short-acting GLP1 agonist lixisenatide in 6068 patients with type 2 diabetes and a recent acute coronary syndrome. Beside cardiovascular safety, the addition of lixisenatide to standard therapy showed beneficial impact on renal outcomes. The renoprotective effect manifested as lower rate of increase in urinary albumin-to-creatinine ratio, $34 \%$ in the placebo group vs. $24 \%$ in lixisenatide group. No significant difference was observed between the two groups in eGFR decline or doubling of serum creatinine, while overall incidence of renal adverse effects was low in both groups. Evidently the difference in pharmacokinetics of GLP-1 analogs, short-acting versus long-acting analogs, has no impact on renal composite outcomes. Somewhat different results were obtained in AWARD-7 study which examined the effect of long acting GLP-1 analog dulaglutide versus insulin glargine on renal outcomes in patients with diabetes type 2 and moderate-to-severe CKD [66]. 577 participants were randomized in three groups, dulaglutide $1.5 \mathrm{mg}$ or $0.75 \mathrm{mg}$ treated groups and insulin glargine group. The decline of eGFR after 52 weeks of treatment with dulaglutide was significantly smaller in dulaglutide treated patients compared to insulin group. The albuminuria decrease was similar between all treatment groups, with a slightly greater decrease of urinary albumin-to-creatinine ratio in dulaglutide treated patients. Although dulaglutide enhanced body loss, whether fat or muscle tissue, the study confirmed the beneficial renal effect of GLP-1 analog as an independent action. In the Trial to Evaluate Cardiovascular and other Long-term Outcomes with Semaglutide in Subjects with Type 2 Diabetes (SUSTAIN-6), the rate of persistent macroalbuminuria was lower in patients receiving semaglutide, than in those receiving placebo [67].

Taken together, GLP-1 analogs as antidiabetic medications show significant influence on renal composite outcomes, primarily on a new onset of macroalbuminuria as shown in Table 1. Numerous previous studies characterized development of albuminuria as an independent predictor of diabetic nephropathy progression with subsequent deterioration of estimated glomerular filtration and development of end stage renal disease [68-70]. Definitely, more intensive glycemic control achieved by addition of GLP-1 agonist to background antidiabetic therapy justifies a decrease of macroalbuminuria incidence in diabetic patients due to a well-known effect of serum high glucose concentration on increased filtration rate of proteins via glomerular capillary membrane and on impaired tubular reabsorption [71]. Another possible mechanism of GLP-1 beneficial renal effect could be suppression of inflammation-related pathways. Preclinical studies have unambiguously demonstrated anti-inflammatory and antioxidative effect of GLP-1 analogs [59,72]. This was also suggested during the LIRA-RENAL trial when lower concentration of inflammation marker hsCRP was obtained in liraglutid treated group in comparison with placebo [63]. Although the mechanism of beneficial renal effect of GLP-1 agonists still remains elusive, it is definitely achieved as a combined effect through glucose lowering treatment and extra-glycemic effects. 
Table 1. The pharmacokinetic properties and renal outcomes of clinical trials with GLP-1 receptor agonists.

\begin{tabular}{|c|c|c|c|c|c|}
\hline Drug. & Dose & Half Life (h) & Elimination & Clinical Study & Renal Benefit \\
\hline \multicolumn{6}{|c|}{ Short-acting GLP-1 receptor agonists } \\
\hline Exenatide & $\begin{array}{l}5-10 \mu \mathrm{g} \\
\text { twice-daily s.c. }\end{array}$ & 2.4 & Mostly renal & / & l \\
\hline Lixisenatide & $\begin{array}{c}10-20 \mu \mathrm{g} \\
\text { once-daily s.c. }\end{array}$ & 3.0 & Mostly renal & ELIXA [65] & $\begin{array}{l}\text { Lower rate of increase in urinary } \\
\text { albumin-to-creatinine ratio }\end{array}$ \\
\hline \multicolumn{6}{|c|}{ Long-acting GLP-1 receptor agonists } \\
\hline Exenatide & 2 mg QW s.c. & 2.4 & Mostly renal & & \\
\hline Liraglutide & $\begin{array}{l}0.6 \mathrm{mg}, 1.2 \mathrm{mg} \text { or } \\
1.8 \mathrm{mg} \text { once-daily } \\
\text { s.c. }\end{array}$ & $11.6-13.0$ & $\begin{array}{c}\text { Peptidases and renal } \\
6 \% \text {; feces } 5 \%\end{array}$ & LEADER [64] & $\begin{array}{l}\downarrow \text { Nephropathy, } \\
\downarrow \text { UACR, } \\
\downarrow \text { RAS hormone, } \\
\downarrow \text { Progression to macroalbuminuria, } \\
\downarrow \text { Doubling of serum creatinine levels, } \\
\downarrow \text { eGFR of } \leq 45 \mathrm{~mL} / \mathrm{min} \text { per } 1.73 \mathrm{~m}^{2}, \\
\downarrow \text { The initiation of renal-replacement therapy, } \\
\downarrow \text { Risk of end-stage renal disease or renal death, } \\
\downarrow \text { Plasma renin concentration, renin activity, } \\
\text { angiotensin II }\end{array}$ \\
\hline Semaglutide & $\begin{array}{c}0.5-1.0 \mathrm{mg} \\
\text { once-weekly s.c. }\end{array}$ & $165.0-184.0$ & Peptidases and renal & SUSTAIN-6 [67] & $\begin{array}{l}\downarrow \text { Nephropathy }>35 \%, \\
\downarrow \text { Progression to macroalbuminuria, } \\
\downarrow \text { Doubling of serum creatinine levels, } \\
\downarrow \text { eGFR of } \leq 45 \mathrm{~mL} / \text { min per } 1.73 \mathrm{~m}^{2}, \\
\downarrow \text { The initiation of renal-replacement therapy }\end{array}$ \\
\hline Dulaglutide & $\begin{array}{c}0.75-1.5 \mathrm{mg} \\
\text { once-weekly s.c. }\end{array}$ & $\sim 112.8$ & Peptidases and renal & AWARD VII [66] & $\begin{array}{l}\text { Reduced albuminuria, slower decline in renal } \\
\text { function }\end{array}$ \\
\hline Albiglutide & $\begin{array}{c}30-50 \mathrm{mg} \\
\text { once-weekly s.c. }\end{array}$ & $\sim 120.0$ & Peptidases and renal & l & l \\
\hline
\end{tabular}

Abbrevations: s.c., subcutaneous injection; eGFR, estimated glomerular filtration rate in $\mathrm{mL} / \mathrm{min} / 1.73 \mathrm{~m}^{2}$; UACR, urine albumin/creatinine ratio; RAS, renin-angiotensin system; CVR, cardiovascular risk, $\downarrow$ decline. 


\section{SGLT2 Inhibitors in Diabetic Nephropathy}

\subsection{Mechanism of Action}

Sodium/glucose cotransporter 2 (SGLT2) inhibitors are orally administrated hypoglycemic drugs with a novel mechanism of action that is useful across a continuum of diabetes regardless of duration of diabetes, baseline Hba1c or concomitant antidiabetic therapy [73,74]. Glucose reabsorbtion takes place in the proximal tubule via the sodium dependent glucose transporters (SGLT), placed on the apical side of the proximal tubule cell through the basolateral Na, K-ATPase pump [75,76]. SGLT2 is expressed almost entirely in the renal proximal tubules, hence selective inhibition of this protein leads to renal glucose excretion and reduction of plasma glucose levels without influencing other metabolic processes [77]. Sodium glucose cotransporter 2 (SGLT2) is the main luminal glucose transporter placed in the S1 and S2 portions of the proximal tubule (PT) while sodium glucose cotransporter 1 (SGLT1) is placed in the S3 portion and supply fewer than $10 \%$ of entire luminal glucose transport [78]. SGLT2 on the apical membrane is connected with GLUT2 on the basolateral part and jointly they reabsorb up to $90 \%$ of filtered glucose beneath normoglycaemic conditions [79]. Increased renin angiotensin system (RAS) activity with SGLT2 inhibition is explained by the normal volume depletion with this kind of therapy [80], although a tendency for diminished GFR with SGLT2 inhibition is probably due to enlarged afferent tone over tubuloglomerular feedback [81]. Furthermore, maximal renoprotection from glomerular injury, renal fibrosis, and proteinuria was achieved when luseogliflozin (SGLT2 inhibitor) was combined with the ACE inhibitor, lisinopril [82]. At the early stage of kidney impairment, therapies that prevent the RAS activity are as well indicated, but these approaches are not completely beneficial [83]. One of the possible mechanisms of SGLT2 inhibitors is prevention of glucose influx to the kidney proximal tubular cell responsible for development of diabetic nephropathy [84-86]. Histological variation detected in the glomerulus is the traditional focal point in diabetic nephropathy, but it has become extensively recognized that the changes detected in tubulointerstitial fibrosis and in the tubulointerstitium correspond more firmly with impairment in renal function [79]. Dapagliflozin, canagliflozin, and empagliflozin are SGLT2i drugs, useful in reducing hyperglycemia and improvement of glycemic control. They are used in mild renal impairment and have combined beneficial effects such as the lowering of body weight and blood pressure (BP) [73]. The pharmacokinetic properties of SGLT2 inhibitors demonstrate an excellent oral bioavailability, a rather long elimination half-life permitting once daily administration, a short accumulation index, no active metabolites and restricted renal excretion [87]. Moreover, these drugs share an insignificant risk of drug-drug interactions [88]. The risk for hypoglycemia is low because inhibition of SGLT2 does not increase the excretion of insulin or impede with gluconeogenesis. Additionally, there are some indications that SGLT2 inhibition improves beta cell function, perhaps by reducing glucotoxicity $[89,90]$. Loss of excess calories mediated by glucose excretion in urine results in weight loss and can alleviate the weight gain induced by another classes of hypoglycemic agents. In patients with hypertension SGLT2 inhibitors lower blood pressure as well, probably due to glucosuria, subsequent natriuresis, and diuresis [91]. Absorption of dapagliflozin after oral administration is fast, reaching peak plasma concentrations in 1-2 $\mathrm{h}$ it. The main organs included in the metabolism of this drug are the liver and kidneys, where inactive metabolites are produced by enzyme uridine diphosphate-glucuronosyltransferase-1A9 (UGT1A9). Clearance of dapagliflozin by renal excretion is not significant, and there are no drug-drug interactions [88]. Dapagliflozin is capable of reducing body weight and fat mass, improving glycemic control and lowering blood pressure [92,93]. Following the treatment of T2DM with 5 or $10 \mathrm{mg}$ dapagliflozin, a higher risk of mild to moderate urinary tract infections was observed, but without a final dose correlatin among UTI and glucosuria [94].Pharmacokinetic properties of canagliflozin include immediate absorption after oral administration, $65 \%$ oral bioavailability within a dose range of $50-300 \mathrm{mg}$, and in dose-dependent manner, high potential as $99 \%$ is bounded to plasma proteins, especially albumin, and finally it is metabolized generally to inactive metabolites [88,95]. As opposed to other SGLT2i, canagliflozin is also capable of minor inhibition of SGLT1. Canagliflozin postpones 
intestinal glucose absorption in addition to increasing UGE, followed by lowering of postprandial glucose and insulin levels [96]. Canagliflozin treatment is also associated with an UTI and symptomatic vulvovaginal adverse events in female patients with T2DM [97]. Empagliflozin is quickly absorbed in single oral doses achieving Cmax after 1.0-2.0 h. Drug-drug interactions among empagliflozin and other oral glucose lowering agents, cardiovascular medications or various other drugs with narrow therapeutic index were not observed $[88,98]$. In a fasting and postprandial state in T2DM patients, following administration of empagliflozin or dapagliflozin, paradoxical increase in endogenous glucose production was demonstrated [99]. Nevertheless, plasma glucose levels in these patients were reduced by empagliflozin [98]. Ferrannini et al. showed moderate association of a 10 and $25 \mathrm{mg}$ empagliflozin dose and increased incidence of genital infections, but without increase in UTIs incidence [100]. The capacity of SGLT2i to decrease the plasma glucose levels is directly proportional to the glomerular filtration rate (GFR) and is reduced in chronic kidney disease (CKD). Nevertheless, research underway indicates that SGLT2i can contribute to nephroprotection in diabetes independently of glycemic control [73,101-103].

\subsection{Evidence of Nephroprotection In Vitro and in Animal Models}

Cultured human proximal renal tubular cells of patients with type 2 diabetes demonstrate noticeably enlarged levels of SGLT2 mRNA and protein and increased glucose transporter activity [104]. Several experiments using human proximal tubular cells (HK2) showed that SGLT2 inhibition reduced the output of inflammatory and fibrotic markers induced by high glucose levels [73]. The above-mentioned in vitro findings suggest that SGLT2 inhibitors can provide nephroprotection in diabetes by blocking glucose influx to proximal tubule cells [105]. In new preclinical trials, nephroprotection with SGLT2 inhibition has been observed after improvement of glycemic control [82,105-109].

Accordingly, the effect of SGLT2 inhibition on early kidney growth, inflammation, and fibrosis was proposed to result from blood glucose lowering [109]. Thus, blood glucose lowering effect could be responsible for SGLT2i inhibition of inflammation, fibrosis and early renal growth [105]. This hypothesis is supported by several recently published studies conducted in animal models. Inhibition of progression of albuminuria along with drop in plasma glucose by $<15 \mathrm{mmol} / \mathrm{L}$ was observed in male $\mathrm{db} / \mathrm{db}$ mice treated with dapagliflozin [107] and females treated with tofogliflozin [109]. Furthermore, Lin et al. showed decrease in albuminuria and glomerulosclerosis followed by improvement of hyperglycemia in male $\mathrm{db} / \mathrm{db}$ mice treated with empagliflozin [108]. Vallon et al. demonstrated reduction of albuminuria, kidney hypertrophy, and markers of inflammation, proportional to glucose lowering effect in the T1DM model of male Akita mice treated with empagliflozin [105]. The effect of SGLT2 inhibition on diabetic nephropathy, autonomous of blood glucose decrease, was investigated in diabetic eNOS knockout mice [110], while further studies in fat Zucker rats have demonstrated that diabetes enhanced RNA expression of SGLT2 and SGLT1 within the kidney [111]. In addition, proximal tubular cells exposed to the urine of diabetic patients have shown an increase in SGLT2 expression [104]. Diversity of agents have been related to the modification in expression of SGLT1 and 2, including HNF1 $\alpha$ and SGK1 [76]. Furthermore, exposure of proximal tubular cells to transforming growth factor $\beta$ (TGF $\beta$ ), a profibrotic cytokine, led to upregulation of SGLT2 expression [66].

Interleukin-6 (IL-6) and tumor necrosis factor- $\alpha$ (TNF- $\alpha$ ) increased SGLT2 expression in cultured kidney cell lines after exposure for 96-120 h [112], while increase in SGLT2 expression has also been achieved through high glucose-induced pathway exceeding protein kinase A (PKA) and protein kinase C (PKC) reliant pathways $[113,114]$. Some studies have also shown interaction among the sodium glucose cotransporters and the renin-angiotensin-aldosterone model. For example, losartan decreased SGLT2 expression in diabetic rats in regular or high salt nutrition in animal models [115]. In diabetic rats, enhancement of GLUT2 expression and its translocation to the luminal surface of the proximal tubular cells was observed leading to an increase in glucose reabsorption [78]. One of the potential mechanisms involved in nephroprotection could be linked with a decrease in GLUT 9 expression, 
a major regulator of urate homeostasis [116-118]. The expression of certain profibrotic genes is diminished with empagliflozin, in line with the effects of first line anti-diabetic agent, metformin in diabetic rat model. Gallo at al. presented that a threshold of blood glucose lowering can be necessary to accomplished complete renoprotection in diabetes, since empagliflozin influenced some markers of fibrosis but had no effect on albuminuria and glomerular sclerosis. So, Gallo et al. suggested that adequate, and stable blood glucose lowering, perhaps with multiple medications, including higherand/or multiple daily-dosing of SGLT2 inhibition in combination with a RAS blockade, can be necessary to accomplished maximal nephroprotection in diabetes [83].

\subsection{Assessment of Nephroprotective Effect of SGLT 2 Inhibitors in Clinical Trials}

Presently, short-term studies are available assuring of renal safety with SGLT2i drugs, however there are no long-term data confirming renal benefit [118] SGLT2i decreases albuminuria, the most important renal risk marker in DN [119]. The albuminuria-lowering effects of SGLT2i have been shown in various studies $[120,121]$ but the precise mechanism is still not clear, and it seems to be independent of alterations in eGFR, systolic BP, body weight, or HbA1c [121]. A placebo-controlled study has demonstrated that canagliflozin $100 \mathrm{mg} /$ day diminished albuminuria around 22\% [120], likewise empagliflozin $25 \mathrm{mg} /$ day decreased albuminuria roughly $35 \%$ relative to placebo in patients with chronic kidney disease and diabetes mellitus type 2 RAS-based drugs such as ACEi or ARBs, and SGLT2i could have complementary but different mechanisms of action, with diverse outcomes to the kidney system and a potential synergistic effect. In a recently published study, the combination of SGLT2i and RAS blockers was associated with additive nephroprotective effect in diabetic nephropathy compared to either medicament alone [106]. Heerspink et al. showed reduction of albuminuria with dapagliflozin $10 \mathrm{mg} /$ day, compared to placebo in patients with hypertension and diabetes already treated with RAS blockers [121].

Decrease of uric acid in serum is another way where SGLT2i may achieve their nephroprotective effect. Elevated levels of uric acid or hyperuricemia, have been demonstrated to hugely correlate with the possibility of renal impairment in diabetes [122-124], and are responsible for microvascular complications in diabetes $[125,126]$. The beneficial effect of uric acid reduction in serum with SGLT2i can be clinically significant and has been shown in several studies [127-129]. The EMPA-REG outcome study has shown that empagliflozin therapy was associated with improvement in all renal function parameters in patients with estimated glomerular filtration rate of at least $30 \mathrm{~mL}$ per minute. Empagliflozin significantly decreased worsening or incident nephropathy, request for renal transplantation or dialysis and doubling of serum creatinine levels compared to placebo, while further analysis showed reduction in albuminuria [67].

In the DECLARE trial there was a $24 \%$ reduction with dapagliflozin in a composite renal outcome of a $\geq 40 \%$ decrease in estimated glomerular filtration rate (eGFR) (to $<60 \mathrm{~mL} / \mathrm{min} / 1.73 \mathrm{~m}^{2}$ ), end-stage renal disease (ESRD), or death from renal or CV causes compared with placebo [130]. Included patients had eGFR of at least $60 \mathrm{~mL} / \mathrm{min}$ at baseline, emphasizing the potential role of dapagliflozin not only in treatment but in the prevention of diabetic nephropathy [131,132]. The CANVAS trial showed a $27 \%$ reduction in progression of albuminuria, with a $40 \%$ reduction in eGFR, need for renal-replacement therapy, or death from renal causes associated with the use of canagliflozin [131]. The CREDENCE study was the first large-scale outcome trial of an SGLT2 inhibitor canagliflozin with primary kidney outcome defined as doubling of serum creatinine, end-stage kidney disease, or death due to cardiovascular or kidney disease. Almost all patients included in the CREDENCE trial (99\%) were treated with ACE inhibitors or ARBs compared to other trials (80\%) [133], and had eGFR of 30 to $<90 \mathrm{~mL}$ per minute as shown in Table 2 . The trial was stopped early after a planned interim analysis based on positive results since the relative risk of the renal-specific composite outcome was lower by $34 \%$ and the relative risk of end-stage kidney disease was lower by $32 \%$. These data demonstrate that renoprotection was accomplished via the whole spectrum of eGFR levels once again establishing nephroprotecitve effect irrispective of baseline kidney function. The nephroprotective 
effects of SGLT2i could also benefit cardiovascular outcomes by triggering neurohormonal activation and volume wasting $[134,135]$. Recent meta-analysis demonstrated that SGLT2 inhibitors reduced the risk of dialysis, transplantation, or death due to kidney disease in individuals with type 2 diabetes and provided protection against acute kidney injury, adding additional evidence endorsing SGLT2i therapy as a corner stone of nephroprotection in diabetics [133]. SGLT2i are not presently recommended in patients with an eGFR lower than $45 \mathrm{~mL} / \mathrm{min}$ per $1.73 \mathrm{~m}^{2}$, to a large degree because of deficient glycemic effectiveness $[136,137]$. Proof of renoprotection from the above mentioned trials, due to these limitations, is questionable [138]. 
Table 2. The pharmacokinetic properties and renal outcomes of clinical trials with SGLT2i.

\begin{tabular}{|c|c|c|c|c|c|}
\hline Drug & Dose (mg) & Half Life (h) & Administration & Clinical Study/Outcome & Renal Benefit \\
\hline Empagliflozin & 10 & 11.9 & Per os, once daily & $\begin{array}{c}\text { EMPA-REG OUTCOME [67]/incident or } \\
\text { worsening nephropathy and incident } \\
\text { albuminuria }\end{array}$ & $\begin{array}{l}\downarrow \text { Nephropathy } 39 \%, \\
\downarrow \text { Progression to macroalbuminuria, } \\
\downarrow \text { Doubling of serum creatinine levels, } \\
\downarrow \text { the initiation of renal-replacement therapy }\end{array}$ \\
\hline Dapagliflozin & 10 & 12.9 & Per os, once daily & $\begin{array}{l}\text { DECLARE [137]/beneficial effects } \\
\text { defined by eGFR status and the } \\
\text { attendance or absence of Atherosclerotic } \\
\text { cardiovascular illness at baseline }\end{array}$ & $\begin{array}{l}\downarrow \text { eGFR of } 40 \% \text { or more to an eGFR of fewer than } \\
60 \mathrm{~mL} / \mathrm{min} \text { per } 1.73 \mathrm{~m}^{2} \text {, } \\
\downarrow \text { Combined risk of end-stage renal disease or } \\
\text { renal death, } \\
\downarrow \text { Early prevention and decrease in progression of } \\
\text { chronic renal disease in patients with T2DM, } 31 \% \\
\text { reduction in the risk of acute renal injury in the } \\
\text { dapagliflozin group compared to placebo group }\end{array}$ \\
\hline Canagliflozin & 100 & over 12 & Per os, once daily & $\begin{array}{l}\text { CANVAS [67,133]/incident albuminuria, } \\
\text { incident of renal failure }\end{array}$ & $\begin{array}{l}\downarrow \text { acute } \\
\downarrow \text { acute kidney injury } \\
\downarrow \text { albuminuria } \\
\downarrow \text { eGFR of } 40 \% \\
\downarrow \text { the initiation of renal-replacementtherapy } \\
\downarrow \text { death from renal causes kidney injury } \\
\downarrow \text { albuminuria } \\
\downarrow \text { eGFR of } 40 \% \\
\downarrow \text { the initiation of renal-replacementtherapy } \\
\downarrow \text { death from renal causes }\end{array}$ \\
\hline & & & & $\begin{array}{c}\text { CREDENCE * }[133] / \text { patients with } \\
\text { established CKD, incident albuminuria, } \\
\text { composite of dialysis, transplantation or } \\
\text { death due to renal disease }\end{array}$ & $\begin{array}{l}\downarrow \text { Acute kidney injury, Albuminuria, } \\
\downarrow \text { eGFR of } 40 \%, \\
\downarrow \text { The initiation of renal-replacement therapy, } \\
\downarrow \text { Death from renal causes in acute kidney injury, } \\
\downarrow \text { Doubling of serum creatinine levels } \\
\downarrow \text { Risk of dialysis and transplantation, } \\
\downarrow \text { Risk of end-stage renal, disease or renal death }\end{array}$ \\
\hline
\end{tabular}




\section{Implications of Potential Synergism of GLP 1 RA and SGLT2 Inhibitors on Prevention of Kidney Disease}

Although glycemic control along with blood pressure control and blockade of renin-angiotensin-aldosterone system represents a cornerstone of the prevention of new-onset diabetic nephropathy, 30\% of diabetic patients will develop significant renal insufficiency [102,139]. Therefore, novel therapeutic measures as well as diabetic polytherapy are a necessity in prevention and treatment of diabetes mellitus associated complications. Recent studies clearly demonstrate the renoprotective effects of GLP-1 receptor agonists primarily achieved through reduction of new onset microalbuminuria [140]. Although the molecular mechanisms of these beneficial effects are not fully clarified some of renal effects of these drugs have been emphasized. GLP1 receptors present in multiple renal cells are responsible for increased glomerular filtration rate, vasodilatation of the afferent arteriole, and enhanced natriuresis [62]. The state of hyperglycaemia causes enhanced reabsorption of $\mathrm{Na}+$ in proximal tubule and reduced delivery of $\mathrm{Na}+$ to the macula densa with consequent vasodilatation of afferent arteriole, glomerular hypertension, and hyperfiltration [4,141]. Both GLP 1 receptor agonists and SGLT2I promote natriuresis within the proximal tubule acting at different sites. Inhibition of SGLT2 co-transporter beside enhanced glucosuria results in increased natiuresis while GLP-1 receptor agonists promote natriuresis through inhibition of NHE3 (sodium hydrogen exchanger-3) transporter in proximale tubule. Increased delivery of $\mathrm{Na}+$ to macula densa due to inhibition of SGLT2 triggers tubuloglomerlar feedback resulting in afferent vasoconstriction, reduced glomerular pressure and a 30-50\% decrease in albuminuria [142]. Despite the natriuretic effect, mechanistic studies and clinical trials failed to exhibit renal hemodynamic vasoconstriction in response to GLP-1 RA treatment resulting in overall neutral GFR effect. However, GLP-1 RA treatment of diabetic patients undoubtedly reduces albuminuria probably due to suppression of inflammation-related pathways [139]. Combination of these antihyperglycemic agents characterizes complementary physiological effect on natriuresis while albuminuria reduction is achieved by different mechanisms. Taken together, potential synergistic and/or additive effects of SGLT2I and GLP-1 receptor agonists at renal function implicate direct beneficial impact on progression of diabetic kidney disease (Figure 1.). In addition, renal benefits could be achieved through common extrarenal effects such as weight reduction and lowering of blood pressure. However, to determine whether a synergistic or additive effect is in question, or perhaps a combination of the two, further studies in vitro and in vivo are needed comparing renal molecular mechanisms and clinical outcomes of combined therapy to each monocomponent separately. 


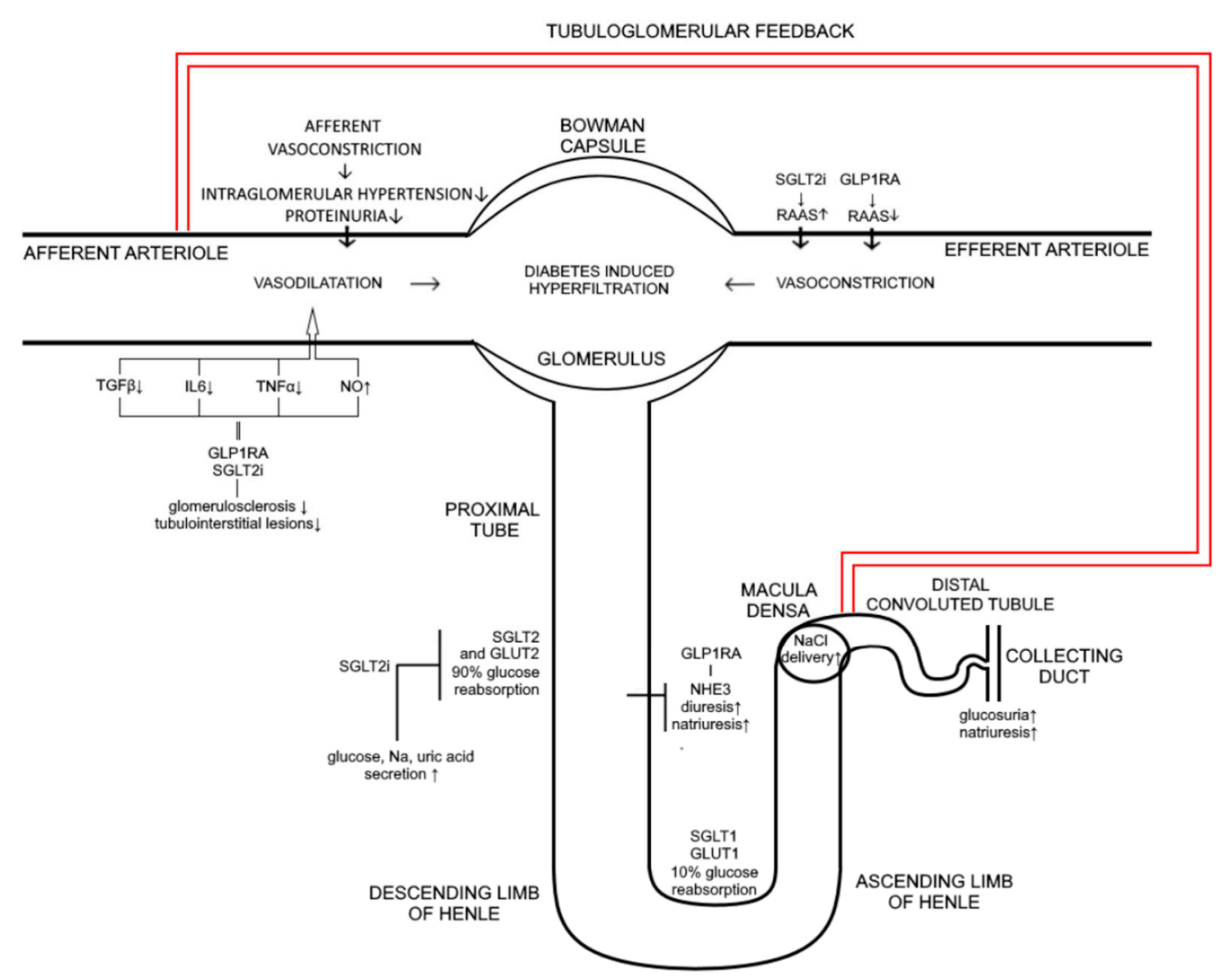

Figure 1. Mechanism of action of SGLT2i and GLP 1RA on kidney. SGLT2i inhibit glucose and sodium transport via SGLT2 and GLUT 2 transporters which are responsible for $90 \%$ of glucose reabsorption thus inducing glucosuria, diuresis, natriuresis, and uric acid excretion. At the same time GLP 1RA via NHE3 are also promoting diuresis and natriuresis. Influx of sodium to macula densa is increased thus affecting afferent vasoconstriction causing reduction in intraglomerular pressure and proteinuria through tubuloglomerular feedback. Both, GLP 1RA and SGLT2i induce suppression of inflammatory markers such as TGF $\beta$, IL6, TNF $\alpha$, decreasing glomerusclerosis and tubulointerstitial lesions and causing afferent vasoconstriction (induction of NO is also involved). GLP 1RA therapy leads to a decrease in RAAS activity causing efferent vasodilatation, while the effect of SGLT2 $\mathrm{i}$ is quite the opposite, it increases RAAS activity due to natriuresis and volume depletion implying that positive effect on intraglomerular pressure is mediated completely through tubuloglomerular feedback; $\uparrow$ increase; $\downarrow$ decrease.

\section{Conclusions}

Both GLP 1 RA and SGLT2i may exhibit direct renoprotective effects through the suppression of inflammatory responses, inhibition of oxidative injury, and prevention of apoptosis as a result of the combined impact of glucose lowering treatment and extra-glycemic effects. Definitely, more intensive glycemic control achieved by addition of GLP-1 agonist and SGLT2i to background antidiabetic therapy justifies a potential benefit on renal function in diabetic patients, however it is obvious that other renoprotective mechanisms exist such as hemodynamic effects, blood pressure control, and body weight loss. Recently, based on the evidence from the trials mentioned above, new European Society of Cardiology (ESC) guidelines in association with European Association for the Study of Diabetes (EASD) position these drugs as the first therapy of choice in patients with diabetes and high cardiovascular risk overthrowing the long-standing paradigm of metformin as the first line therapy in DMT2 [143]. Given the importance of cardiovascular and renal risk reduction in diabetic patients achieved with those therapeutic options, it is only a matter of time before these two classes of drugs will become the gold standard in the treatment of type 2 diabetes. 
Author Contributions: V.N. and T.O.K. conceived of and designed the article, and critically revised the manuscript; I.B.Ć. performed critical revision of the manuscript for important intellectual content, obtained funding, and provided administrative, technical and material support; H.R. and T.K. performed literature searches and critical revision of the manuscript for important intellectual content; M.S. performed literature searches, wrote the manuscript, and updated the text of the paper; M.S. performed literature searches and wrote the manuscript.

Funding: APC was funded by University project, VIF-2018-FDMZ-06.

Conflicts of Interest: The authors declare no conflict of interest.

\section{Abbreviations}

$\begin{array}{ll}\text { SGLT2i } & \text { sodium glucose lowering transporter2 inhibitors } \\ \text { GLP1 RA } & \text { glucagon like peptide 1 receptor agonist } \\ \text { GLUT } 2 & \text { glucose transporter } 2 \\ \text { NHE3 } & \text { sodium-hydrogen exchanger isoform } 3 \\ \text { TGF } \beta & \text { transforming growth factor } \beta \\ \text { IL6 } & \text { interleukin } 6 \\ \text { TNF } \alpha & \text { transforming nuclear factor } \alpha \\ \text { RAAS } & \text { renin-angiotensin-aldosterone system }\end{array}$

\section{References}

1. Thomas, B. The Global Burden of Diabetic Kidney Disease: Time Trends and Gender Gaps. Curr. Diabet. Rep. 2019, 19, 18. [CrossRef] [PubMed]

2. Zha, F.; Bai, L.; Tang, B.; Li, J.; Wang, Y.; Zheng, P.; Ji, T.; Bai, S. MicroRNA-503 contributes to podocyte injury via targeting E2F3 in diabetic nephropathy. J. Cell Biochem. 2019, 120, 12574-12581. [CrossRef] [PubMed]

3. Murea, M.; Ma, L.; Freedman, B.I. Genetic and environmental factors associated with type 2 diabetes and diabetic vascular complications. Rev. Diabet. Stud. 2012, 9, 6-22. [CrossRef] [PubMed]

4. Abbiss, H.; Maker, G.L.; Trengove, R.D. Metabolomics Approaches for the Diagnosis and Understanding of Kidney Diseases. Metabolites 2019, 9, 34. [CrossRef] [PubMed]

5. Gross, J.L.; de Azevedo, M.J.; Silveiro, S.P.; Canani, L.H.; Caramori, M.L.; Zelmanovitz, T. Diabetic nephropathy: Diagnosis, prevention, and treatment. Diabetes Care 2005, 28, 164-176. [CrossRef] [PubMed]

6. Parving, H.H.; Lehnert, H.; Bröchner-Mortensen, J.; Gomis, R.; Andersen, S.; Arner, P. Irbesartan in Patients with Type 2 Diabetes and Microalbuminuria Study Group. The effect of irbesartan on the development of diabetic nephropathy in patients with type 2 diabetes. N. Engl. J. Med. 2001, 345, 870-878. [CrossRef]

7. Van der Kloet, F.M.; Tempels, F.W.; Ismail, N.; van der Heijden, R.; Kasper, P.T.; Rojas-Cherto, M.; van Doorn, R.; Spijksma, G.; Koek, M.; van der Greef, J.; et al. Discovery of early-stage biomarkers for diabetic kidney disease using ms-based metabolomics (FinnDiane study). Metabolomics 2012, 8, 109-119. [CrossRef]

8. Zelmanovitz, T.; Gerchman, F.; Balthazar, A.P.; Thomazelli, F.C.; Matos, J.D.; Canani, L.H. Diabetic nephropathy. Diabet. Metab. Syndr. 2009, 1, 10. [CrossRef]

9. Yoon, J.J.; Park, J.H.; Kim, H.J.; Jin, H.G.; Kim, H.Y.; Ahn, Y.M.; Kim, Y.C.; Lee, H.S.; Lee, Y.J.; Kang, D.G. Improves Glomerular Fibrosis and Renal Dysfunction in Diabetic Nephropathy Model. Nutrients 2019, 11, 553. [CrossRef]

10. Declèves, A.E.; Sharma, K. New pharmacological treatments for improving renal outcomes in diabetes. Nat. Rev. Nephrol 2010, 6, 371-380. [CrossRef]

11. Mogensen, C.E.; Christensen, C.K. Predicting diabetic nephropathy in insulin-dependent patients. N. Engl. J. Med. 1984, 311, 89-93. [CrossRef] [PubMed]

12. Parving, H.H.; Oxenbøll, B.; Svendsen, P.A.; Christiansen, J.S.; Andersen, A.R. Early detection of patients at risk of developing diabetic nephropathy. A longitudinal study of urinary albumin excretion. Acta Endocrinol. (Copenh) 1982, 100, 550-555. [CrossRef] [PubMed]

13. Viberti, G.C.; Hill, R.D.; Jarrett, R.J.; Argyropoulos, A.; Mahmud, U.; Keen, H. Microalbuminuria as a predictor of clinical nephropathy in insulin-dependent diabetes mellitus. Lancet 1982, 1, 1430-1432. [CrossRef]

14. Cao, Z.; Cooper, M.E. Pathogenesis of diabetic nephropathy. J. Diabet. Investig. 2011, 2, 243-247. [CrossRef] [PubMed] 
15. Wei, L.; Xiao, Y.; Li, L.; Xiong, X.; Han, Y.; Zhu, X.; Sun, L. The Susceptibility Genes in Diabetic Nephropathy. Kidney Dis. (Basel) 2018, 4, 226-237. [CrossRef] [PubMed]

16. Mahmoodnia, L.; Aghadavod, E.; Beigrezaei, S.; Rafieian-Kopaei, M. An update on diabetic kidney disease, oxidative stress and antioxidant agents. J. Renal. Inj. Prev. 2017, 6, 153-157. [CrossRef] [PubMed]

17. Pichler, R.; Afkarian, M.; Dieter, B.P.; Tuttle, K.R. Immunity and inflammation in diabetic kidney disease: Translating mechanisms to biomarkers and treatment targets. Am. J. Physiol. Ren. Physiol. 2017, 312, F716-F731. [CrossRef]

18. Hill, C.J.; Cardwell, C.R.; Patterson, C.C.; Maxwell, A.P.; Magee, G.M.; Young, R.J.; Matthews, B.; O'Donoghue, D.J.; Fogarty, D.G. Chronic kidney disease and diabetes in the national health service: A cross-sectional survey of the U.K. national diabetes audit. Diabet. Med. 2014, 31, 448-454. [CrossRef]

19. McDonough, C.W.; Palmer, N.D.; Hicks, P.J.; Roh, B.H.; An, S.S.; Cooke, J.N.; Hester, J.M.; Wing, M.R.; Bostrom, M.A.; Rudock, M.E.; et al. A genome-wide association study for diabetic nephropathy genes in African Americans. Kidney Int. 2011, 79, 563-572. [CrossRef]

20. Lindblom, R.; Higgins, G.; Coughlan, M.; de Haan, J.B. Targeting Mitochondria and Reactive Oxygen Species-Driven Pathogenesis in Diabetic Nephropathy. Rev. Diabet. Stud. 2015, 12, 134-156. [CrossRef]

21. Mittal, M.; Siddiqui, M.R.; Tran, K.; Reddy, S.P.; Malik, A.B. Reactive oxygen species in inflammation and tissue injury. Antioxid. Redox Signal. 2014, 20, 1126-1167. [CrossRef] [PubMed]

22. Kizivat, T.; Smolić, M.; Marić, I.; Tolušić Levak, M.; Smolić, R.; Bilić Čurčić, I.; Kuna, L.; Mihaljević, I.; Včev, A.; Tucak-Zorić, S. Antioxidant Pre-Treatment Reduces the Toxic Effects of Oxalate on Renal Epithelial Cells in a Cell Culture Model of Urolithiasis. Int. J. Environ. Res. Public Health 2017, 14, 109. [CrossRef] [PubMed]

23. Fioretto, P.; Caramori, M.L.; Mauer, M. The kidney in diabetes: Dynamic pathways of injury and repair. The Camillo Golgi Lecture 2007. Diabetologia 2008, 51, 1347-1355. [CrossRef] [PubMed]

24. Tervaert, T.W.; Mooyaart, A.L.; Amann, K.; Cohen, A.H.; Cook, H.T.; Drachenberg, C.B.; Ferrario, F.; Fogo, A.B.; Haas, M.; de Heer, E.; et al. Pathologic classification of diabetic nephropathy. J. Am. Soc. Nephrol. 2010, 21, 556-563. [CrossRef] [PubMed]

25. Alicic, R.Z.; Rooney, M.T.; Tuttle, K.R. Diabetic Kidney Disease: Challenges, Progress, and Possibilities. Clin. J. Am. Soc. Nephrol. 2017, 12, 2032-2045. [CrossRef] [PubMed]

26. Tyagi, I.; Agrawal, U.; Amitabh, V.; Jain, A.K.; Saxena, S. Thickness of glomerular and tubular basement membranes in preclinical and clinical stages of diabetic nephropathy. Indian J. Nephrol. 2008, 18, 64-69. [CrossRef]

27. Fioretto, P.; Mauer, M. Histopathology of diabetic nephropathy. Semin. Nephrol. 2007, 27, 195-207. [CrossRef]

28. Caramori, M.L.; Parks, A.; Mauer, M. Renal lesions predict progression of diabetic nephropathy in type 1 diabetes. J. Am. Soc. Nephrol. 2013, 24, 1175-1181. [CrossRef]

29. Drummond, K.; Mauer, M.; Group, I.D.N.S. The early natural history of nephropathy in type 1 diabetes: II. Early renal structural changes in type 1 diabetes. Diabetes 2002, 51, 1580-1587. [CrossRef]

30. Osterby, R.; Tapia, J.; Nyberg, G.; Tencer, J.; Willner, J.; Rippe, B.; Torffvit, O. Renal structures in type 2 diabetic patients with elevated albumin excretion rate. APMIS 2001, 109, 751-761. [CrossRef]

31. Saito, Y.; Kida, H.; Takeda, S.; Yoshimura, M.; Yokoyama, H.; Koshino, Y.; Hattori, N. Mesangiolysis in diabetic glomeruli: Its role in the formation of nodular lesions. Kidney Int. 1988, 34, 389-396. [CrossRef] [PubMed]

32. Stout, L.C.; Kumar, S.; Whorton, E.B. Focal mesangiolysis and the pathogenesis of the Kimmelstiel-Wilson nodule. Hum. Pathol. 1993, 24, 77-89. [CrossRef]

33. Gentilella, R.; Pechtner, V.; Corcos, A.; Consoli, A. Glucagon-like peptide-1 receptor agonists in type 2 diabetes treatment: Are they all the same? Diabetes Metab Res. Rev. 2019, 35, e3070. [CrossRef] [PubMed]

34. Gallwitz, B. Glucagon-like peptide-1 receptor agonists. In Handbook of Incretin-Based Therapies in Type 2 Diabetes; Gough, S., Ed.; Springer International Publishing Switzerland: Cham, Switzerland, 2016; pp. 31-43.

35. Baggio, L.L.; Drucker, D.J. Biology of incretins: GLP-1 and GIP. Gastroenterology 2007, 132, $2131-2157$. [CrossRef]

36. Turton, M.D.; O'Shea, D.; Gunn, I.; Beak, S.A.; Edwards, C.M.; Meeran, K.; Choi, S.J.; Taylor, G.M.; Heath, M.M.; Lambert, P.D.; et al. A role for glucagon-like peptide-1 in the central regulation of feeding. Nature 1996, 379, 69-72. [CrossRef] 
37. Zhao, X.; Liu, G.; Shen, H.; Gao, B.; Li, X.; Fu, J.; Zhou, J.; Ji, Q. Liraglutide inhibits autophagy and apoptosis induced by high glucose through GLP-1R in renal tubular epithelial cells. Int. J. Mol. Med. 2015, 35, 684-692. [CrossRef]

38. Nauck, M.A.; Duran, S.; Kim, D.; Johns, D.; Northrup, J.; Festa, A.; Brodows, R.; Trautmann, M. A comparison of twice-daily exenatide and biphasic insulin aspart in patients with type 2 diabetes who were suboptimally controlled with sulfonylurea and metformin: A non-inferiority study. Diabetologia 2007, 50, $259-267$. [CrossRef]

39. Buse, J.B.; Bergenstal, R.M.; Glass, L.C.; Heilmann, C.R.; Lewis, M.S.; Kwan, A.Y.; Hoogwerf, B.J.; Rosenstock, J. Use of twice-daily exenatide in Basal insulin-treated patients with type 2 diabetes: A randomized, controlled trial. Ann. Intern. Med. 2011, 154, 103-112. [CrossRef]

40. Weissman, P.N.; Carr, M.C.; Ye, J.; Cirkel, D.T.; Stewart, M.; Perry, C.; Pratley, R. HARMONY 4: Randomised clinical trial comparing once-weekly albiglutide and insulin glargine in patients with type 2 diabetes inadequately controlled with metformin with or without sulfonylurea. Diabetologia 2014, 57, 2475-2484. [CrossRef]

41. Wysham, C.; Blevins, T.; Arakaki, R.; Colon, G.; Garcia, P.; Atisso, C.; Kuhstoss, D.; Lakshmanan, M. Efficacy and safety of dulaglutide added onto pioglitazone and metformin versus exenatide in type 2 diabetes in a randomized controlled trial (AWARD-1). Diabetes Care 2014, 37, 2159-2167. [CrossRef]

42. Nauck, M.; Weinstock, R.S.; Umpierrez, G.E.; Guerci, B.; Skrivanek, Z.; Milicevic, Z. Efficacy and safety of dulaglutide versus sitagliptin after 52 weeks in type 2 diabetes in a randomized controlled trial (AWARD-5). Diabetes Care 2014, 37, 2149-2158. [CrossRef]

43. Drucker, D.J.; Buse, J.B.; Taylor, K.; Kendall, D.M.; Trautmann, M.; Zhuang, D.; Porter, L.; Group, D.-S. Exenatide once weekly versus twice daily for the treatment of type 2 diabetes: A randomised, open-label, non-inferiority study. Lancet 2008, 372, 1240-1250. [CrossRef]

44. Blevins, T.; Pullman, J.; Malloy, J.; Yan, P.; Taylor, K.; Schulteis, C.; Trautmann, M.; Porter, L. DURATION-5: Exenatide once weekly resulted in greater improvements in glycemic control compared with exenatide twice daily in patients with type 2 diabetes. J. Clin. Endocrinol. Metab. 2011, 96, 1301-1310. [CrossRef]

45. Buse, J.B.; Drucker, D.J.; Taylor, K.L.; Kim, T.; Walsh, B.; Hu, H.; Wilhelm, K.; Trautmann, M.; Shen, L.Z.; Porter, L.E.; et al. DURATION-1: Exenatide once weekly produces sustained glycemic control and weight loss over 52 weeks. Diabetes Care 2010, 33, 1255-1261. [CrossRef]

46. Buse, J.B.; Rosenstock, J.; Sesti, G.; Schmidt, W.E.; Montanya, E.; Brett, J.H.; Zychma, M.; Blonde, L.; Group, L.-S. Liraglutide once a day versus exenatide twice a day for type 2 diabetes: A 26-week randomised, parallel-group, multinational, open-label trial (LEAD-6). Lancet 2009, 374, 39-47. [CrossRef]

47. Abd El Aziz, M.S.; Kahle, M.; Meier, J.J.; Nauck, M.A. A meta-analysis comparing clinical effects of short- or long-acting GLP-1 receptor agonists versus insulin treatment from head-to-head studies in type 2 diabetic patients. Diabetes Obes. Metab. 2017, 19, 216-227. [CrossRef]

48. Zaccardi, F.; Htike, Z.Z.; Webb, D.R.; Khunti, K.; Davies, M.J. Benefits and Harms of Once-Weekly Glucagon-like Peptide-1 Receptor Agonist Treatments: A Systematic Review and Network Meta-analysis. Ann. Intern. Med. 2016, 164, 102-113. [CrossRef]

49. DeFronzo, R.A.; Ratner, R.E.; Han, J.; Kim, D.D.; Fineman, M.S.; Baron, A.D. Effects of exenatide (exendin-4) on glycemic control and weight over 30 weeks in metformin-treated patients with type 2 diabetes. Diabetes Care 2005, 28, 1092-1100. [CrossRef]

50. Lorenz, M.; Evers, A.; Wagner, M. Recent progress and future options in the development of GLP-1 receptor agonists for the treatment of diabesity. Bioorg Med. Chem. Lett. 2013, 23, 4011-4018. [CrossRef]

51. Yin, W.; Xu, S.; Wang, Z.; Liu, H.; Peng, L.; Fang, Q.; Deng, T.; Zhang, W.; Lou, J. Recombinant human GLP-1(rhGLP-1) alleviating renal tubulointestitial injury in diabetic STZ-induced rats. Biochem. Biophys. Res. Commun. 2018, 495, 793-800. [CrossRef]

52. Hills, C.E.; Al-Rasheed, N.; Willars, G.B.; Brunskill, N.J. C-peptide reverses TGF-beta1-induced changes in renal proximal tubular cells: Implications for treatment of diabetic nephropathy. Am. J. Physiol. Ren. Physiol. 2009, 296, F614-F621. [CrossRef] [PubMed]

53. Kodera, R.; Shikata, K.; Kataoka, H.U.; Takatsuka, T.; Miyamoto, S.; Sasaki, M.; Kajitani, N.; Nishishita, S.; Sarai, K.; Hirota, D.; et al. Glucagon-like peptide-1 receptor agonist ameliorates renal injury through its anti-inflammatory action without lowering blood glucose level in a rat model of type 1 diabetes. Diabetologia 2011, 54, 965-978. [CrossRef] [PubMed] 
54. Leech, C.A.; Holz, G.G.; Habener, J.F. Signal transduction of PACAP and GLP-1 in pancreatic beta cells. Ann. N. Y. Acad. Sci. 1996, 805, 81-92. [CrossRef]

55. Holz, G.G. Epac: A new cAMP-binding protein in support of glucagon-like peptide-1 receptor-mediated signal transduction in the pancreatic beta-cell. Diabetes 2004, 53, 5-13. [CrossRef]

56. Bengis-Garber, C.; Gruener, N. Protein kinase A downregulates the phosphorylation of p47 phox in human neutrophils: A possible pathway for inhibition of the respiratory burst. Cell Signal. 1996, 8, 291-296. [CrossRef]

57. Savitha, G.; Salimath, B.P. Cross-talk between protein kinase C and protein kinase A down-regulates the respiratory burst in polymorphonuclear leukocytes. Cell Signal. 1993, 5, 107-117. [CrossRef]

58. Hendarto, H.; Inoguchi, T.; Maeda, Y.; Ikeda, N.; Zheng, J.; Takei, R.; Yokomizo, H.; Hirata, E.; Sonoda, N.; Takayanagi, R. GLP-1 analog liraglutide protects against oxidative stress and albuminuria in streptozotocin-induced diabetic rats via protein kinase A-mediated inhibition of renal NAD(P)H oxidases. Metabolism 2012, 61, 1422-1434. [CrossRef]

59. Fujita, H.; Morii, T.; Fujishima, H.; Sato, T.; Shimizu, T.; Hosoba, M.; Tsukiyama, K.; Narita, T.; Takahashi, T.; Drucker, D.J.; et al. The protective roles of GLP-1R signaling in diabetic nephropathy: Possible mechanism and therapeutic potential. Kidney Int. 2014, 85, 579-589. [CrossRef]

60. Gutzwiller, J.P.; Hruz, P.; Huber, A.R.; Hamel, C.; Zehnder, C.; Drewe, J.; Gutmann, H.; Stanga, Z.; Vogel, D.; Beglinger, C. Glucagon-like peptide- 1 is involved in sodium and water homeostasis in humans. Digestion 2006, 73, 142-150. [CrossRef]

61. Rieg, T.; Gerasimova, M.; Murray, F.; Masuda, T.; Tang, T.; Rose, M.; Drucker, D.J.; Vallon, V. Natriuretic effect by exendin-4, but not the DPP-4 inhibitor alogliptin, is mediated via the GLP-1 receptor and preserved in obese type 2 diabetic mice. Am. J. Physiol. Renal. Physiol. 2012, 303, F963-F971. [CrossRef]

62. Muskiet, M.H.A.; Tonneijck, L.; Smits, M.M.; van Baar, M.J.B.; Kramer, M.H.H.; Hoorn, E.J.; Joles, J.A.; van Raalte, D.H. GLP-1 and the kidney: From physiology to pharmacology and outcomes in diabetes. Nat. Rev. Nephrol. 2017, 13, 605-628. [CrossRef]

63. Davies, M.J.; Bain, S.C.; Atkin, S.L.; Rossing, P.; Scott, D.; Shamkhalova, M.S.; Bosch-Traberg, H.; Syrén, A.; Umpierrez, G.E. Efficacy and Safety of Liraglutide Versus Placebo as Add-on to Glucose-Lowering Therapy in Patients with Type 2 Diabetes and Moderate Renal Impairment (LIRA-RENAL): A Randomized Clinical Trial. Diabetes Care 2016, 39, 222-230. [CrossRef]

64. Mann, J.F.E.; Ørsted, D.D.; Buse, J.B. Liraglutide and Renal Outcomes in Type 2 Diabetes. N. Engl. J. Med. 2017, 377, 2197-2198. [CrossRef]

65. Muskiet, M.H.A.; Tonneijck, L.; Huang, Y.; Liu, M.; Saremi, A.; Heerspink, H.J.L.; van Raalte, D.H. Lixisenatide and renal outcomes in patients with type 2 diabetes and acute coronary syndrome: An exploratory analysis of the ELIXA randomised, placebo-controlled trial. Lancet Diabetes Endocrinol. 2018, 6, 859-869. [CrossRef]

66. Tuttle, K.R.; Lakshmanan, M.C.; Rayner, B.; Busch, R.S.; Zimmermann, A.G.; Woodward, D.B.; Botros, F.T. Dulaglutide versus insulin glargine in patients with type 2 diabetes and moderate-to-severe chronic kidney disease (AWARD-7): A multicentre, open-label, randomised trial. Lancet Diabetes Endocrinol. 2018, 6, 605-617. [CrossRef]

67. De Vos, L.C.; Hettige, T.S.; Cooper, M.E. New Glucose-Lowering Agents for Diabetic Kidney Disease. Adv. Chronic Kidney Dis. 2018, 25, 149-157. [CrossRef] [PubMed]

68. Fuhrman, D.Y.; Schneider, M.F.; Dell, K.M.; Blydt-Hansen, T.D.; Mak, R.; Saland, J.M.; Furth, S.L.; Warady, B.A.; Moxey-Mims, M.M.; Schwartz, G.J. Albuminuria, Proteinuria, and Renal Disease Progression in Children with CKD. Clin. J. Am. Soc. Nephrol. 2017, 12, 912-920. [CrossRef]

69. Fox, C.S.; Matsushita, K.; Woodward, M.; Bilo, H.J.; Chalmers, J.; Heerspink, H.J.; Lee, B.J.; Perkins, R.M.; Rossing, P.; Sairenchi, T.; et al. Associations of kidney disease measures with mortality and end-stage renal disease in individuals with and without diabetes: A meta-analysis. Lancet 2012, 380, 1662-1673. [CrossRef]

70. Lorenzo, V.; Saracho, R.; Zamora, J.; Rufino, M.; Torres, A. Similar renal decline in diabetic and non-diabetic patients with comparable levels of albuminuria. Nephrol. Dial. Transplant. 2010, 25, 835-841. [CrossRef]

71. Marso, S.P.; Bain, S.C.; Consoli, A.; Eliaschewitz, F.G.; Jódar, E.; Leiter, L.A.; Lingvay, I.; Rosenstock, J.; Seufert, J.; Warren, M.L.; et al. Semaglutide and Cardiovascular Outcomes in Patients with Type 2 Diabetes. N. Engl. J. Med. 2016, 375, 1834-1844. [CrossRef]

72. Muskiet, M.H.; Smits, M.M.; Morsink, L.M.; Diamant, M. The gut-renal axis: Do incretin-based agents confer renoprotection in diabetes? Nat. Rev. Nephrol. 2014, 10, 88-103. [CrossRef] 
73. Panchapakesan, U.; Pegg, K.; Gross, S.; Komala, M.G.; Mudaliar, H.; Forbes, J.; Pollock, C.; Mather, A. Effects of SGLT2 inhibition in human kidney proximal tubular cells-Renoprotection in diabetic nephropathy? PLoS ONE 2013, 8, e54442. [CrossRef]

74. Katz, P.M.; Leiter, L.A. The Role of the Kidney and SGLT2 Inhibitors in Type 2 Diabetes. Can. J. Diabetes 2015, 39 (Suppl. S5), S167-S175. [CrossRef]

75. Mather, A.; Pollock, C. Glucose handling by the kidney. Kidney Int. Suppl. 2011, 79, S1-S6. [CrossRef]

76. Mather, A.; Pollock, C. Renal glucose transporters: Novel targets for hyperglycemia management. Nat. Rev. Nephrol. 2010, 6, 307-311. [CrossRef]

77. Abdul-Ghani, M.A.; DeFronzo, R.A.; Norton, L. Novel hypothesis to explain why SGLT2 inhibitors inhibit only 30-50\% of filtered glucose load in humans. Diabetes 2013, 62, 3324-3328. [CrossRef]

78. Marks, J.; Carvou, N.J.; Debnam, E.S.; Srai, S.K.; Unwin, R.J. Diabetes increases facilitative glucose uptake and GLUT2 expression at the rat proximal tubule brush border membrane. J. Physiol. 2003, 553, $137-145$. [CrossRef]

79. Gilbert, R.E.; Cooper, M.E. The tubulointerstitium in progressive diabetic kidney disease: More than an aftermath of glomerular injury? Kidney Int. 1999, 56, 1627-1637. [CrossRef]

80. Cherney, D.Z.; Perkins, B.A.; Soleymanlou, N.; Xiao, F.; Zimpelmann, J.; Woerle, H.J.; Johansen, O.E.; Broedl, U.C.; von Eynatten, M.; Burns, K.D. Sodium glucose cotransport-2 inhibition and intrarenal RAS activity in people with type 1 diabetes. Kidney Int. 2014, 86, 1057-1058. [CrossRef]

81. Vallon, V.; Richter, K.; Blantz, R.C.; Thomson, S.; Osswald, H. Glomerular hyperfiltration in experimental diabetes mellitus: Potential role of tubular reabsorption. J. Am. Soc. Nephrol. 1999, 10, 2569-2576.

82. Kojima, N.; Williams, J.M.; Slaughter, T.N.; Kato, S.; Takahashi, T.; Miyata, N.; Roman, R.J. Renoprotective effects of combined SGLT2 and ACE inhibitor therapy in diabetic Dahl S rats. Physiol. Rep. 2015, 3, e12436. [CrossRef]

83. Gallo, L.A.; Ward, M.S.; Fotheringham, A.K.; Zhuang, A.; Borg, D.J.; Flemming, N.B.; Harvie, B.M.; Kinneally, T.L.; Yeh, S.M.; McCarthy, D.A.; et al. Erratum: Once daily administration of the SGLT2 inhibitor, empagliflozin, attenuates markers of renal fibrosis without improving albuminuria in diabetic $\mathrm{db} / \mathrm{db}$ mice. Sci. Rep. 2016, 6, 28124. [CrossRef]

84. Johnson, D.W.; Saunders, H.J.; Brew, B.K.; Poronnik, P.; Cook, D.I.; Field, M.J.; Pollock, C.A. TGF-beta 1 dissociates human proximal tubule cell growth and $\mathrm{Na}(+)-\mathrm{H}+$ exchange activity. Kidney Int. 1998, 53, 1601-1607. [CrossRef]

85. Panchapakesan, U.; Pollock, C.A.; Chen, X.M. The effect of high glucose and PPAR-gamma agonists on PPAR-gamma expression and function in HK-2 cells. Am. J. Physiol Renal Physiol. 2004, 287, F528-F534. [CrossRef]

86. Qi, W.; Chen, X.; Holian, J.; Mreich, E.; Twigg, S.; Gilbert, R.E.; Pollock, C.A. Transforming growth factor-beta1 differentially mediates fibronectin and inflammatory cytokine expression in kidney tubular cells. Am. J. Physiol. Renal Physiol. 2006, 291, F1070-F1077. [CrossRef]

87. Scheen, A.J. Evaluating SGLT2 inhibitors for type 2 diabetes: Pharmacokinetic and toxicological considerations. Expert Opin. Drug Metab. Toxicol. 2014, 10, 647-663. [CrossRef]

88. Scheen, A.J. Drug-drug interactions with sodium-glucose cotransporters type 2 (SGLT2) inhibitors, new oral glucose-lowering agents for the management of type 2 diabetes mellitus. Clin. Pharmacokinet. 2014, 53, 295-304. [CrossRef]

89. Merovci, A.; Mari, A.; Solis-Herrera, C.; Xiong, J.; Daniele, G.; Chavez-Velazquez, A.; Tripathy, D.; Urban McCarthy, S.; Abdul-Ghani, M.; DeFronzo, R.A. Dapagliflozin lowers plasma glucose concentration and improves $\beta$-cell function. J. Clin. Endocrinol. Metab. 2015, 100, 1927-1932. [CrossRef]

90. Del Prato, S. Role of glucotoxicity and lipotoxicity in the pathophysiology of Type 2 diabetes mellitus and emerging treatment strategies. Diabet. Med. 2009, 26, 1185-1192. [CrossRef]

91. Wilding, J.P.; Blonde, L.; Leiter, L.A.; Cerdas, S.; Tong, C.; Yee, J.; Meininger, G. Efficacy and safety of canagliflozin by baseline HbA1c and known duration of type 2 diabetes mellitus. J. Diabetes Complic. 2015, 29, 438-444. [CrossRef]

92. Bolinder, J.; Ljunggren, Ö.; Johansson, L.; Wilding, J.; Langkilde, A.M.; Sjöström, C.D.; Sugg, J.; Parikh, S. Dapagliflozin maintains glycaemic control while reducing weight and body fat mass over 2 years in patients with type 2 diabetes mellitus inadequately controlled on metformin. Diabetes Obes. Metab. 2014, 16, 159-169. [CrossRef] 
93. Engeli, S.; Jordan, J. Novel metabolic drugs and blood pressure: Implications for the treatment of obese hypertensive patients? Curr. Hypertens Rep. 2013, 15, 470-474. [CrossRef]

94. Johnsson, K.M.; Ptaszynska, A.; Schmitz, B.; Sugg, J.; Parikh, S.J.; List, J.F. Urinary tract infections in patients with diabetes treated with dapagliflozin. J. Diabetes Complic. 2013, 27, 473-478. [CrossRef]

95. Elkinson, S.; Scott, L.J. Canagliflozin: First global approval. Drugs 2013, 73, 979-988. [CrossRef]

96. Polidori, D.; Sha, S.; Mudaliar, S.; Ciaraldi, T.P.; Ghosh, A.; Vaccaro, N.; Farrell, K.; Rothenberg, P.; Henry, R.R. Canagliflozin lowers postprandial glucose and insulin by delaying intestinal glucose absorption in addition to increasing urinary glucose excretion: Results of a randomized, placebo-controlled study. Diabetes Care 2013, 36, 2154-2161. [CrossRef]

97. Nyirjesy, P.; Zhao, Y.; Ways, K.; Usiskin, K. Evaluation of vulvovaginal symptoms and Candida colonization in women with type 2 diabetes mellitus treated with canagliflozin, a sodium glucose co-transporter 2 inhibitor. Curr. Med. Res. Opin. 2012, 28, 1173-1178. [CrossRef]

98. Scheen, A.J. Pharmacokinetic and pharmacodynamic profile of empagliflozin, a sodium glucose co-transporter 2 inhibitor. Clin. Pharmacokinet. 2014, 53, 213-225. [CrossRef]

99. Ferrannini, E.; Muscelli, E.; Frascerra, S.; Baldi, S.; Mari, A.; Heise, T.; Broedl, U.C.; Woerle, H.J. Metabolic response to sodium-glucose cotransporter 2 inhibition in type 2 diabetic patients. J. Clin. Invest. 2014, 124, 499-508. [CrossRef]

100. Ferrannini, E.; Berk, A.; Hantel, S.; Pinnetti, S.; Hach, T.; Woerle, H.J.; Broedl, U.C. Long-term safety and efficacy of empagliflozin, sitagliptin, and metformin: An active-controlled, parallel-group, randomized, 78-week open-label extension study in patients with type 2 diabetes. Diabetes Care 2013, 36, 4015-4021. [CrossRef]

101. Gerich, J.E. Role of the kidney in normal glucose homeostasis and in the hyperglycaemia of diabetes mellitus: Therapeutic implications. Diabet. Med. 2010, 27, 136-142. [CrossRef]

102. Cherney, D.Z.; Scholey, J.W.; Jiang, S.; Har, R.; Lai, V.; Sochett, E.B.; Reich, H.N. The effect of direct renin inhibition alone and in combination with ACE inhibition on endothelial function, arterial stiffness, and renal function in type 1 diabetes. Diabetes Care 2012, 35, 2324-2330. [CrossRef] [PubMed]

103. De Nicola, L.; Gabbai, F.B.; Liberti, M.E.; Sagliocca, A.; Conte, G.; Minutolo, R. Sodium/glucose cotransporter 2 inhibitors and prevention of diabetic nephropathy: Targeting the renal tubule in diabetes. Am. J. Kidney Dis. 2014, 64, 16-24. [CrossRef] [PubMed]

104. Rahmoune, H.; Thompson, P.W.; Ward, J.M.; Smith, C.D.; Hong, G.; Brown, J. Glucose transporters in human renal proximal tubular cells isolated from the urine of patients with non-insulin-dependent diabetes. Diabetes 2005, 54, 3427-3434. [CrossRef] [PubMed]

105. Vallon, V.; Gerasimova, M.; Rose, M.A.; Masuda, T.; Satriano, J.; Mayoux, E.; Koepsell, H.; Thomson, S.C.; Rieg, T. SGLT2 inhibitor empagliflozin reduces renal growth and albuminuria in proportion to hyperglycemia and prevents glomerular hyperfiltration in diabetic Akita mice. Am. J. Physiol. Renal Physiol. 2014, 306, F194-F204. [CrossRef] [PubMed]

106. Kojima, N.; Williams, J.M.; Takahashi, T.; Miyata, N.; Roman, R.J. Effects of a new SGLT2 inhibitor, luseogliflozin, on diabetic nephropathy in T2DN rats. J. Pharmacol. Exp. Ther. 2013, 345, 464-472. [CrossRef] [PubMed]

107. Terami, N.; Ogawa, D.; Tachibana, H.; Hatanaka, T.; Wada, J.; Nakatsuka, A.; Eguchi, J.; Horiguchi, C.S.; Nishii, N.; Yamada, H.; et al. Long-term treatment with the sodium glucose cotransporter 2 inhibitor, dapagliflozin, ameliorates glucose homeostasis and diabetic nephropathy in $\mathrm{db} / \mathrm{db}$ mice. PLoS ONE 2014, 9, e100777. [CrossRef] [PubMed]

108. Lin, B.; Koibuchi, N.; Hasegawa, Y.; Sueta, D.; Toyama, K.; Uekawa, K.; Ma, M.; Nakagawa, T.; Kusaka, H.; Kim-Mitsuyama, S. Glycemic control with empagliflozin, a novel selective SGLT2 inhibitor, ameliorates cardiovascular injury and cognitive dysfunction in obese and type 2 diabetic mice. Cardiovasc. Diabetol. 2014, 13, 148. [CrossRef]

109. Nagata, T.; Fukuzawa, T.; Takeda, M.; Fukazawa, M.; Mori, T.; Nihei, T.; Honda, K.; Suzuki, Y.; Kawabe, Y. Tofogliflozin, a novel sodium-glucose co-transporter 2 inhibitor, improves renal and pancreatic function in db/db mice. Br. J. Pharmacol. 2013, 170, 519-531. [CrossRef] [PubMed]

110. Gangadharan Komala, M.; Gross, S.; Mudaliar, H.; Huang, C.; Pegg, K.; Mather, A.; Shen, S.; Pollock, C.A.; Panchapakesan, U. Inhibition of kidney proximal tubular glucose reabsorption does not prevent against diabetic nephropathy in type 1 diabetic eNOS knockout mice. PLoS ONE 2014, 9, e108994. [CrossRef] 
111. Tabatabai, N.M.; Sharma, M.; Blumenthal, S.S.; Petering, D.H. Enhanced expressions of sodium-glucose cotransporters in the kidneys of diabetic Zucker rats. Diabetes Res. Clin. Pract. 2009, 83, e27-e30. [CrossRef]

112. Maldonado-Cervantes, M.I.; Galicia, O.G.; Moreno-Jaime, B.; Zapata-Morales, J.R.; Montoya-Contreras, A.; Bautista-Perez, R.; Martinez-Morales, F. Autocrine modulation of glucose transporter SGLT2 by IL-6 and TNF- $\alpha$ in LLC-PK(1) cells. J. Physiol. Biochem. 2012, 68, 411-420. [CrossRef] [PubMed]

113. Beloto-Silva, O.; Machado, U.F.; Oliveira-Souza, M. Glucose-induced regulation of NHEs activity and SGLTs expression involves the PKA signaling pathway. J. Membr. Biol. 2011, 239, 157-165. [CrossRef] [PubMed]

114. Ghezzi, C.; Wright, E.M. Regulation of the human Na+-dependent glucose cotransporter hSGLT2. Am. J. Physiol. Cell Physiol. 2012, 303, C348-C354. [CrossRef] [PubMed]

115. Osorio, H.; Bautista, R.; Rios, A.; Franco, M.; Santamaría, J.; Escalante, B. Effect of treatment with losartan on salt sensitivity and SGLT2 expression in hypertensive diabetic rats. Diabetes Res. Clin. Pract. 2009, 86, e46-e49. [CrossRef] [PubMed]

116. Doblado, M.; Moley, K.H. Facilitative glucose transporter 9, a unique hexose and urate transporter. Am. J. Physiol. Endocrinol. Metab. 2009, 297, E831-E835. [CrossRef] [PubMed]

117. Cain, L.; Shankar, A.; Ducatman, A.M.; Steenland, K. The relationship between serum uric acid and chronic kidney disease among Appalachian adults. Nephrol. Dial. Transplant. 2010, 25, 3593-3599. [CrossRef]

118. Komala, M.G.; Panchapakesan, U.; Pollock, C.; Mather, A. Sodium glucose cotransporter 2 and the diabetic kidney. Curr. Opin. Nephrol. Hypertens 2013, 22, 113-119. [CrossRef]

119. De Zeeuw, D.; Remuzzi, G.; Parving, H.H.; Keane, W.F.; Zhang, Z.; Shahinfar, S.; Snapinn, S.; Cooper, M.E.; Mitch, W.E.; Brenner, B.M. Proteinuria, a target for renoprotection in patients with type 2 diabetic nephropathy: Lessons from RENAAL. Kidney Int. 2004, 65, 2309-2320. [CrossRef]

120. Yale, J.F.; Bakris, G.; Cariou, B.; Yue, D.; David-Neto, E.; Xi, L.; Figueroa, K.; Wajs, E.; Usiskin, K.; Meininger, G. Efficacy and safety of canagliflozin in subjects with type 2 diabetes and chronic kidney disease. Diabetes Obes. Metab. 2013, 15, 463-473. [CrossRef]

121. Heerspink, H.J.; Johnsson, E.; Gause-Nilsson, I.; Cain, V.A.; Sjöström, C.D. Dapagliflozin reduces albuminuria in patients with diabetes and hypertension receiving renin-angiotensin blockers. Diabetes Obes. Metab. 2016, 18, 590-597. [CrossRef]

122. Chonchol, M.; Shlipak, M.G.; Katz, R.; Sarnak, M.J.; Newman, A.B.; Siscovick, D.S.; Kestenbaum, B.; Carney, J.K.; Fried, L.F. Relationship of uric acid with progression of kidney disease. Am. J. Kidney Dis. 2007, 50, 239-247. [CrossRef] [PubMed]

123. Goicoechea, M.; de Vinuesa, S.G.; Verdalles, U.; Ruiz-Caro, C.; Ampuero, J.; Rincón, A.; Arroyo, D.; Luño, J. Effect of allopurinol in chronic kidney disease progression and cardiovascular risk. Clin. J. Am. Soc. Nephrol. 2010, 5, 1388-1393. [CrossRef] [PubMed]

124. Iseki, K.; Oshiro, S.; Tozawa, M.; Iseki, C.; Ikemiya, Y.; Takishita, S. Significance of hyperuricemia on the early detection of renal failure in a cohort of screened subjects. Hypertens Res. 2001, 24, 691-697. [CrossRef] [PubMed]

125. Hovind, P.; Rossing, P.; Johnson, R.J.; Parving, H.H. Serum uric acid as a new player in the development of diabetic nephropathy. J. Ren. Nutr. 2011, 21, 124-127. [CrossRef]

126. Kang, D.H.; Nakagawa, T.; Feng, L.; Watanabe, S.; Han, L.; Mazzali, M.; Truong, L.; Harris, R.; Johnson, R.J. A role for uric acid in the progression of renal disease. J. Am. Soc. Nephrol. 2002, 13, 2888-2897. [CrossRef]

127. Cefalu, W.T.; Leiter, L.A.; Yoon, K.H.; Arias, P.; Niskanen, L.; Xie, J.; Balis, D.A.; Canovatchel, W.; Meininger, G. Efficacy and safety of canagliflozin versus glimepiride in patients with type 2 diabetes inadequately controlled with metformin (CANTATA-SU): 52 week results from a randomised, double-blind, phase 3 non-inferiority trial. Lancet 2013, 382, 941-950. [CrossRef]

128. Bailey, C.J.; Gross, J.L.; Pieters, A.; Bastien, A.; List, J.F. Effect of dapagliflozin in patients with type 2 diabetes who have inadequate glycaemic control with metformin: A randomised, double-blind, placebo-controlled trial. Lancet 2010, 375, 2223-2233. [CrossRef]

129. Wilding, J.P.; Ferrannini, E.; Fonseca, V.A.; Wilpshaar, W.; Dhanjal, P.; Houzer, A. Efficacy and safety of ipragliflozin in patients with type 2 diabetes inadequately controlled on metformin: A dose-finding study. Diabetes Obes. Metab. 2013, 15, 403-409. [CrossRef]

130. Home, P. Cardiovascular outcome trials of glucose-lowering medications: An update. Diabetologia 2019, 62, 357-369. [CrossRef] 
131. Neal, B.; Perkovic, V.; Matthews, D.R. Canagliflozin and Cardiovascular and Renal Events in Type 2 Diabetes. N. Engl. J. Med. 2017, 377, 2099. [CrossRef]

132. Mosenzon, O.; Wiviott, S.D.; Cahn, A.; Rozenberg, A.; Yanuv, I.; Goodrich, E.L.; Murphy, S.A.; Heerspink, H.J.L.; Zelniker, T.A.; Dwyer, J.P.; et al. Effects of dapagliflozin on development and progression of kidney disease in patients with type 2 diabetes: An analysis from the DECLARE-TIMI 58 randomised trial. Lancet Diabetes Endocrinol. 2019, 7, 606-617. [CrossRef]

133. Neuen, B.L.; Young, T.; Heerspink, H.J.L.; Neal, B.; Perkovic, V.; Billot, L.; Mahaffey, K.W.; Charytan, D.M.; Wheeler, D.C.; Arnott, C.; et al. SGLT2 inhibitors for the prevention of kidney failure in patients with type 2 diabetes: A systematic review and meta-analysis. Lancet Diabetes Endocrinol. 2019, 7, 845-854. [CrossRef]

134. Zinman, B.; Wanner, C.; Lachin, J.M.; Fitchett, D.; Bluhmki, E.; Hantel, S.; Mattheus, M.; Devins, T.; Johansen, O.E.; Woerle, H.J.; et al. Empagliflozin, Cardiovascular Outcomes, and Mortality in Type 2 Diabetes. N. Engl. J. Med. 2015, 373, 2117-2128. [CrossRef] [PubMed]

135. Schernthaner, G.; Schernthaner-Reiter, M.H.; Schernthaner, G.H. EMPA-REG and Other Cardiovascular Outcome Trials of Glucose-lowering Agents: Implications for Future Treatment Strategies in Type 2 Diabetes Mellitus. Clin. Ther. 2016, 38, 1288-1298. [CrossRef] [PubMed]

136. Kalra, S.; Singh, V.; Nagrale, D. Sodium-Glucose Cotransporter-2 Inhibition and the Glomerulus: A Review. Adv. Ther. 2016, 33, 1502-1518. [CrossRef] [PubMed]

137. Heerspink, H.J.L.; Kosiborod, M.; Inzucchi, S.E.; Cherney, D.Z.I. Renoprotective effects of sodium-glucose cotransporter-2 inhibitors. Kidney Int. 2018, 94, 26-39. [CrossRef]

138. Molitch, M.E.; Adler, A.I.; Flyvbjerg, A.; Nelson, R.G.; So, W.Y.; Wanner, C.; Kasiske, B.L.; Wheeler, D.C.; de Zeeuw, D.; Mogensen, C.E. Diabetic kidney disease: A clinical update from Kidney Disease: Improving Global Outcomes. Kidney Int. 2015, 87, 20-30. [CrossRef]

139. Cherney, D.Z.I.; Bakris, G.L. Novel therapies for diabetic kidney disease. Kidney Int. Suppl. 2018, 8, 18-25. [CrossRef]

140. Bloomgarden, Z. The kidney and cardiovascular outcome trials. J. Diabetes 2018, 10, 88-89. [CrossRef]

141. Yaribeygi, H.; Atkin, S.L.; Katsiki, N.; Sahebkar, A. Narrative review of the effects of antidiabetic drugs on albuminuria. J. Cell Physiol. 2019, 234, 5786-5797. [CrossRef]

142. León Jiménez, D.; Cherney, D.Z.I.; Bjornstad, P.; Guerra, L.C.; Miramontes González, J.P. Antihyperglycemic agents as novel natriuretic therapies in diabetic kidney disease. Am. J. Physiol. Renal Physiol. 2018, 315, F1406-F1415. [CrossRef] [PubMed]

143. Cosentino, F.; Grant, P.J.; Aboyans, V.; Bailey, C.J.; Ceriello, A.; Delgado, V.; Federici, M.; Filippatos, G.; Grobbee, D.E.; Hansen, T.B.; et al. 2019 ESC Guidelines on diabetes, pre-diabetes, and cardiovascular diseases developed in collaboration with the EASD. Eur. Heart J. 2019. [CrossRef] [PubMed] 